616. $381-089.85: 612766.1$

開腹術前後に於ける疲労反応の消長並に之に

及汪す早期離床, 温泉浴の影響

\author{
第 1 編 \\ 二,三外科手術前後飞於ける浜崎氏 \\ 尿ケトエノ一ル物質の消長 \\ 岡山大学温泉研究所外科 \\ 助手仲原泰博 \\ 〔昭和 34 年 5 月 20 日受稿〕
}

第 1 章 緒 論

第 2 章 各種疾患に於ける尿 KES に就て

第 1 節 緒 言

第 2 節 尿 KES の測定法並に実験症例

第 1 項 尿 KES の测定法

第 2 項 奏験症例

第 3 節 実験成績並に考按

第 1 項 健康人の場合

第 2 項 胃十二指腸潰湯の場合

1）溃湯非合併例

口）出血性潰湯例

八）幽門狭窄例

第 3 項 胃癌の場合

1）胃切除例

口) 单開腹例

第 4 項 胆石症の場合

1) 間歇期例

口) 急性炎症期例

第 5 項 急性虫垂炎の場合

第 6 項 虫垂穿孔性急性腹膜炎の場合

第 7 項 漬富穿孔性急性腹膜炎の場合

第 8 項 イレウスの場合

笨4節 小 括

第 3 章 開腹術前後の尿 KES の変動

\section{第 1 章楮感}

浜崎教授の研究(12)3)470)に成る尿ケトエノール 物筫（以下 KES と略記す）は Purinbasen 及び
次

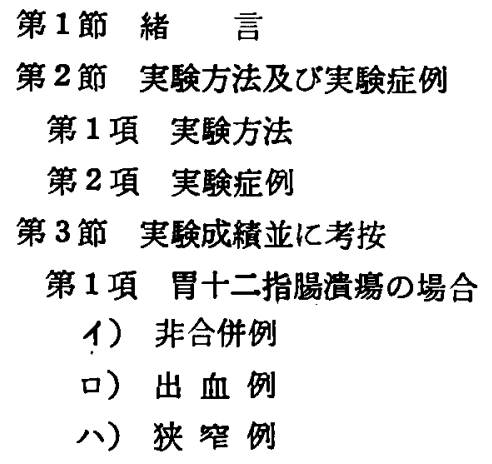

第 2 項 周癌の場合

1）胃切除例

口) 単開腹例

八）街後合併症例

第 3 項 胆石症の場合

1）胆石症間歇期胆赛剔出例

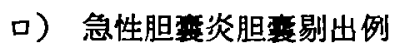

八） 術後肺炎合併例

第 4 項 急性虫垂炎の場合

第 5 項 急性腹膜炎の場合

1）虫垂穿孔性急性腹膜炎の場合

口）清咳穿孔性急性腹膜炎の場合

第 6 項 イレウスの場合

第 4 節 小 括

第 4 章 総括及び結論

Lipoid が主体でその他少量の Kreatinin 及び尿色 素を含有するもので化学的に単一のあのではないが， 本物質は高等動物の組織内には広く分布し，珠に重 要臟器中に豊富に存在する，固定により酸化されて 
ケトンを形成し次でエノール化され，之が不度及び 塩基性フクシンと反応して一新色素を形成して呈色 反応を現わす物質である．浜崎教授はこれをケトエ ノール形成物澌と名付け游離核酸の分解過程に従つ てケトエノールクローム顆粒，ケトエノール鉄顆柆， ケトエノール永顆柆に区別し, 組織内に於て各々形 態学的並に組織化学的に一定の特異性を現わすむの であり，之等は相関眑して一種の物質代謝系繶を形 成し，結局終末産物であるケトエノール永物質とし て尿中に排泄されると云われる．従つて尿中に排泄 される KES の量及び性状を㭘するてとにより体内 の KES 代謝状況を推知し 得る訳である. 尿 KES は肉体的並に精神的労作の過程に応して増量し而も 化学的に所謂疲労物質の一部を構成する物質であつ て之を計量して疲労を判定するのは最も学術的仁信 頼するに足る渡学判定法であると浜崎教授は述へて (る6).

正常健康人の早朝尿 KES 量については重盛7), 甲斐8)，小川99)等の報告があるが浜崎教授10) は通常 0.003 0.01 cc（早朝尿 $10 \mathrm{cc}$ 中）之述べている.

次に外科手術前後の KES 測定成績では先づ患者 尿に就ては西井11) が150例の各種疾患につき KES を測定し 0.01 以下は $42.6 \%$ で，その中癌 23 例では $0.0123 \pm 0.0016$ ，慢性疾患では13例平场 $0.0045 \pm$ 0.00077 之報告している. 安原, 小林12) は虫垂炎患 者の KES の変動を追及し術前値では病勢の悪化せ るものほど高值で術後の経過では病勢に一致して増 減し, 予後判定に有用之述へている，時岡13）蚛虫 垂切除術,アレキサンダー手術, バッシ二氏手術の 術前後の KES を測定し術後第 1 日目に高值を示す が良好なる経過の際は何れも相似た曲線を描き術後 第 $5 \sim 7$ 日で術前值に復帰する，KES の減量遅延 若しくは再异滕の場合は術後の経過異常乃至は合併 症を考虑すへしと述へている．又肺結核の術前後に 関しては甲斐 - 中岡8) は肋膜外合成樹脂充填術 46 例 の前後について KES の消長を検索し術後第 $2 \sim 4$ 日で最高檤を示し術前値に比へ著明に增加し第 5 日 以降手術に基く KES 冒の增加は渐次減少の傾向を 示すという。文難波 14 ) は肺葉切除 7 例術前後では 術前平均 0.007 亿対し術後第 1 日平均 1.53 ，第 3 日 1.65を最高にして徐々に減少し第 7 日は0.17と下降, 胸廓成形術第 1 次手術の16例では術前値0.011，第 2 日最高で0.958，第 7 日0.030之下降，第 2 次手術 の11例では術前平均 0.006 ，第 2 日最高で 1.13 ，第 7 日0.07亿下降，球出成形術の 6 例では術前 0.007 ,
第 4 日最高で1.25，第 7 日0.03に下降するといい， “超つて術後の KES 增量の程度は手術侵㜔の程度に 平行し術後第 $2 \sim 3$ 日で最高值飞達し約 1 週間後に 術前値に近付くという.

以上諸氏の報告の如く尿 KES は手術の前後に於 てほぼ一定の消長を示し術後 $1 \sim 4$ 日で最高值に增 量し約 1 週後に術前值に近付く．上つて手術的侵整 の生体に及ぼす影響を判定するに足る疲学測定法で あつて，私は本法により二，三の外科的矣患の術前 後の疲学を測定し更に続編に述へる術後の早期離床 並に温泉浴の尿 KES の消長に及ばす影響を検討す る基礎的資料之する。

\section{第2 章 各種疾患に於ける尿 KES に就て}

第 1 節 緒 言

私は外科臨床上，比較的屡々遭遇する若干の疾患 に就て早朝尿 KES 量を測定し以後の研究に対する 基本的知見とした。

第2 篇 尿 KES の測定法並に実験症例

第 1 項 尿 KES の測定法

排尿毎に新鮮尿に就て検查することが望ましいか 臨床的には仲々困難であるので私は浜崎教授(5)，小 川16)，時岡17) の研究に従つて早朝第 1 氺を用い糖 (ニーランデル氏法)，蛋白（ズルホサリチル酸法） 陽性のものは䇴涂外し, 被検尿を滤過しその $10 \mathrm{cc}$ を同量の試薬（昇永 $4.0 \mathrm{~g}$ ，硫酸曹達 $1.0 \mathrm{~g}$, 蒸溜水 $100 \mathrm{cc}$ に使用時新鮮なる水醋酸 $6 \mathrm{cc}$ を加え たもの）之共に浜崎氏沈潄管に納め，之を $2 \sim 3$ 回 反転した後室温に直立しておき沈溅管壁に附着して いる微細顆柆を細い竹べらで時々豩離沈下せしめ。 管底に沈滜した KES が密着した24時間後に基底に 沈澱した KES を沈泚管壁に刻んだ目盛で計量した。

\section{第 2 項 実験症例}

本研究実験例はわが研究所外科入院患者で手術に より又組織学的に猃断の確定した 150 例を選んだ. 又対照として既往歴並に現症より健康と見做し得る 男女成人20例任就き测定した。

第 3 節 実踰成精並に考按（表 1 ）

第 1 項 健康人の場合

対照として男女健康成人20例に就き测定した早朝 尿 KES 量は0.002以下 $10 \%, 0.003 \sim 0.01 ， 85 \% て ゙$ 大部分を占め， 0.01 以上は0.012 1 例， 5 \%で平均 值は0.006であつた。重盛7)は324例（13 20才） の女工で0.01以下は13.1\%で0.01以上は86.9\%, 平 
表 1 各種疾患飞於ける尿 KES量

\begin{tabular}{|c|c|c|c|c|c|c|c|}
\hline \multirow[b]{2}{*}{ 患 } & \multirow[b]{2}{*}{ 例 数 } & \multicolumn{5}{|c|}{ 尿 KES 量 } & \multirow{2}{*}{ 平均! } \\
\hline & & $\begin{array}{l}0.00 \\
\sim 0.002\end{array}$ & $\begin{array}{l}0.003 \\
\sim 0.010 \\
\end{array}$ & $\begin{array}{l}0.011 \\
\sim 0.10\end{array}$ & $\begin{array}{r}0.101 \\
\sim 1.0\end{array}$ & $1.01 \sim$ & \\
\hline 康 & 20例 & $10 \%$ & $85 \%$ & $5 \%$ & & & 0.006 \\
\hline 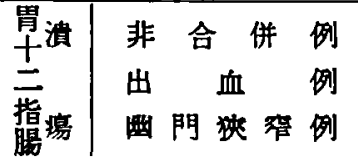 & $\begin{array}{r}52 \\
6 \\
7\end{array}$ & $3.8 \prime \prime$ & $\begin{array}{l}34.7 " \prime \\
16.7 " \\
14.3 \prime \prime\end{array}$ & $\begin{array}{l}44.2 " \prime \\
16.7 " \\
57.1 "\end{array}$ & $\begin{array}{c}15.4 \% \\
50 " \\
28.6 "\end{array}$ & $\begin{array}{r}1.996 \\
16.6 " \prime\end{array}$ & $\begin{array}{l}0.107 \\
0.439 \\
0.208\end{array}$ \\
\hline $\begin{array}{llll}\text { 胃 } & \text { 切 } & \text { 除 } & \text { 例 } \\
\text { 単 } & \text { 開 } & \text { 腹 } & \text { 例 }\end{array}$ & $\begin{array}{l}26 \\
11\end{array}$ & & $\begin{array}{c}11.6 " \prime \\
9 " \prime\end{array}$ & $\begin{array}{c}50 " \prime \\
18.2 "\end{array}$ & $\begin{array}{l}30.7 \prime \prime \\
45.5 \prime \prime\end{array}$ & $\begin{array}{r}7.7 \prime \prime \\
27.3 \prime \prime\end{array}$ & $\begin{array}{l}0.216 \\
0.627\end{array}$ \\
\hline $\begin{array}{l}\text { 間 歇 期 例 } \\
\text { 急性炎症期 例 }\end{array}$ & $\begin{array}{r}14 \\
6\end{array}$ & & $14.3 "$ & $50 "$ & $\begin{array}{l}21.4 \prime \prime \\
33.3 " \prime\end{array}$ & $\begin{array}{l}14.3 \prime \prime \\
66.7 " \prime\end{array}$ & $\begin{array}{l}0.309 \\
1.185\end{array}$ \\
\hline 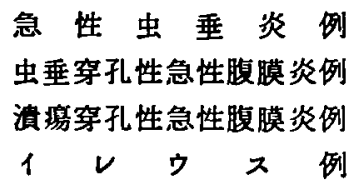 & $\begin{array}{r}14 \\
6 \\
3 \\
5\end{array}$ & & & & $\begin{array}{l}64.3 \prime \prime \\
16.7 \prime \prime \\
80 "\end{array}$ & $\begin{array}{r}35.7 " \\
83.3 " \\
100 " \\
20 "\end{array}$ & $\begin{array}{l}0.54 \\
1.45 \\
2.5 \\
0.73\end{array}$ \\
\hline
\end{tabular}

均0.054 と述へ，甲斐等8) は男女健康成人20例で 0.01 0.1か $90 \%$ ，平均 0.028 之記載し何れる私の例 より高いが，小川 9 は703例の健康な海軍兵学校男 子で0.01以下が89.4\%と述へ，浜崎教授10) は健康 成人朝尿では $0.003 \sim 0.01$ と記し，私は成績は後二 者の測定値とほほ一致する。

第 2 項 胃十二指腸潰場の場合

胃十二指腸漬诸例の早朝尿 KES に就てはま之ま つた報告は殆んど見出し得ず，わづかに西井11)の 3 例では0.005以下の成績がみられるのみであるが, 私の測定值では次の如く 3 群分けて述へる。

1）出血，狭窄等の合併症のない57例の胃十二 指腸溃湯では表 1 の如く 0.002 以下 2 例 $3.8 \%$, $0.003 \sim 0.01$ 18例34.7\%，0.011 0.10 23例44.2\%， $0.101 \sim 1.08$ 例 15.4\%，1.01以上 1 例 $1.9 \%$ で, $0.011 \sim 0.124$ 例, $0.003 \sim 0.01$ 18例, 計 42 例 80.8 \%が大部分を占め平均 0.107 で煡康者に比べ高值を 示す.

口）昍血，下血䎲よる大量の出血後，手術で湝 演底よりの出血を確認した 6 例では0.003〜0.01 1 例，0.011 0.1 1 例，0.101 1.0 3 例，1.01以上 1 例で0.01以上83.3\%で著明に增量し平均值 0.439 の高值であつた。

八）幽門狭窄の 7例では0.01 0.1 4 例, 0.101 $\sim 1.02$ 例， 1.01 以上 1 例，平均値 0.208 で出血例 に比へやや低いが 1）群に比へて高值であつた。

即与胃十二指腸溃鈳では一般に正常值より增量す るが出血例並に狭窄例では増量著明である。
第 3 項 胃癌の場合

浜崎教授は癌では一般に增量すると述べ，西井は 子宮癌 16 例中 9 例か 0.01 以上であり，他の癌 7 例中 5 例が0.01以上となつているが私の胃癌37例に就て の測定值を次の 2 群に分けて述へると

1）根治手術可能の胃切除26例では0.003 0.01 3 例 $(11.6 \%$ ), $0.011 \sim 0.1013$ 例 (50\%), 0.101 $\sim 1.08$ 例 $(30.7 \%), 1.01$ 以上 2 例 $(7.7 \%$ ) で平 均值は0.216である.

口）単開腹例即ち根治手術不能のため単開腹に 䅂つた罚癌末期の11例では 0.01 以下 1 例 ( 9 \%), $0.011 \sim 0.12$ 例 (18.2\%), $0.101 \sim 1.05$ 例 (45.5 \%)，1.01以上 3 例 (27.3\%) で平均值0.627の著明 な高值を示す。

即ち胃癌では高值を示し殊に腹水や広汎転移を伴 う癌末期では著明の増量例が多い.

第4 項 胆石症の場合

西井の胆石症 2 例は 0.035 の記载をみるが私の測 定した20例中イ）間歇期手術施行例14例の成績では 0.01 以下 2 例 $(14.3 \%), 0.011 \sim 0.17$ 例 (50\%), $0.101 \sim 1.03$ 例 $(21.4 \%), 1.01$ 以上 2 例 (14.3\%) で平均值は0.309で高い.

口）急性炎症期, 臨床所見の急迫より止むなく 手術した 6 例では全例著明な增量を認め0.1 1.0 2 例 (33.3\%)，1.0以上 4 例 $(66.7 \%)$ で平均值は 1.185にまでも達した。

即ち胆石症間歇期に於ても正常值より遥加に增量 しているが急性炎症期では殊に著明である。 
第 5 項 急性虫垂炎の場合

虫垂炎患者の尿 KES に就ては安原等は術前值で は急性虫垂炎は一般に高值でしかも病勢の悪化せる むのほど高く次で虫垂炎性膿演であり慢性虫垂炎で は増加が著明でないといい，時岡も急性虫垂炎で高 值を示すと述ぺている．私は14例の非穿孔性急性虫 垂炎の術前尿 KES を測定したが同様の傾向が見ら れ, 0.101 1.0 9 例 (64.3\%)，1.01以上 5 例35.7 \%, 平均值0.54の高値を示す.

第 6 項 虫垂穿孔性急性腹膜炎の場合 6 例共著明の増量を示し0.9 2.5で平均 1.45 であ つた.

第 7 項 潰演穿孔性急性腹膜炎の場合

3 例中 2 例死亡, 何れも術前值 1.5 3.3で平均 2.5の最高值を示す.

第8 項 イレウスの場合

イレウス 5 例では0.4 1.2で0.1〜1.04 例（80 \%)，1.0以上 1 例（20\%）で，平均値0.73である.

第4節 小 括

以上総計 150 例の日常遭遇する腹部外科的疾患に 就て早朝尿（急性疾患では術前杘）の KES 量湘定 成績を述べたが之を概観するに急性炎症疾患では最 あ高度に増量を示し，その順位を平均值よりみれば

1）潰瘍穿孔性急性腹膜炎例

2）虫垂穿孔性急性腹膜炎例

3) 胆石症急性炎症期例

4）韭穿孔性急性虫垂炎例

の順位でほぼ病勢の重篤度に平行していると考えら れる．急性症のイレウスは 3)〜4）の間の平均值を 示し重篤度に相当した高値である.

次に非炎症性疾患では，覀性腫瘍末期たる胃癌根 治手術不能の単開腹例加最も高く，即ち

1) 胃癌単開腹例

2) 馈演出血例

3) 胆石症間歇期例

4) 胃温胃切除例

5）潰婸狭窄例

6）溃場非合併例

の順位である．即ち合併症のない胃十二指腸漬瘍例 が尿 KES 量は最も少いがしかし，健康者に比較す。 るとやや著明の増量を示している。

第 3 章 開腹術前後の尿 KES の变峌

第1節緒言

第 2 章に於て 2，3 の外科的疾患の尿 KES 最
に就き検討したが本章に於ては開腹術前後の尿 KES の変動を追及した成績を報告する，術前後の 尿 KESの変動に関しては前述の如く甲斐，中岡は 助膜外合成樹脂球充填術の術前及び術後最長 1 ケ年 に亘り，難波は肺葉切除，球出成形術，第 1 次並に 第 2 次胸廓成形術の術前及び術後約 1 週にわたり尿 KES を追及した成績を報告している，安原，小林 は急性虫垂炎, 虫垂炎性膿瑒, 慢性虫垂炎の術前及 び術後約10日間，時岡は虫垂切除術，バッシ二氏手 術，アレキサンダー手術の術前及び術後約10日間に わたり尿 KES の変動を追及した. しかしながら， 胃切除術，胆䌛剔出術の如き比較的大なる開腹術の 前後にわたり尿 KES の消長を追及した成樍は少い ようである.

\section{第2 節 実験方法及び実験症例}

\section{第 1 項 実験方法}

第 2 章に述べた尿 KES 測定法により，早朝尿に 就き術前より術後第 $1 \sim 7$ 日まで毎日，以後第10， 13，16，20日に测定した。

第 2 項 実験症例

第 2 章に述べた症例の一部につき测定した，本実 験症例は何れも術後第 5 日までは就床, 術後第 7 日 抜糸後，第 8 日より歩行を開始した．即ち従来惯行 の雖床法を守らせた。

\section{第 3 節 実験成績並に考按（表 2）}

第 1 項 胃十二指腸溃掦の場合

3群に分けて述へる，1）群は術前後を通じて著 明の合併症なく順調に経過退院した症例で，口）群 は突然の吐血又は下血を以て発病来院したもの， 八）群は術前著明な狭窄症状を以て来院手術した症 例である．以上は全例局所麻酔及び内臟神経麻酔に よつて胃切除を行つたむのである.

1）非合併例（第 1 脑）

10例，何れも手術前後にわたり約 $500 \mathrm{cc} の$ 新鮮血 輸血及び約 $5000 \mathrm{cc}$ の輸液を受けている．之等10例 の平均值に就てみれば，術前0.020に対し術後第1,

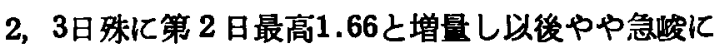
下降し術後第 7 日に0.1以下となり第13日0.083で術 前值とほぼ等しく第16日以後は0.01以下の正常域に 入る.

口）出血例（第 2 図）

4 例，術前後にわたり $1000 \sim 1500 \mathrm{cc}$ 前後の新鮮 血輸血及ひ55000 8000 cc 前後の輸液を受けてい る. 術前値平均0.44で高值を示し，術後第 2 日1.9 で最高値，第 5 日1.0，第 7 日0.3と下降し術前值以 
表 2 開腹術前後の尿 KES 量の変動

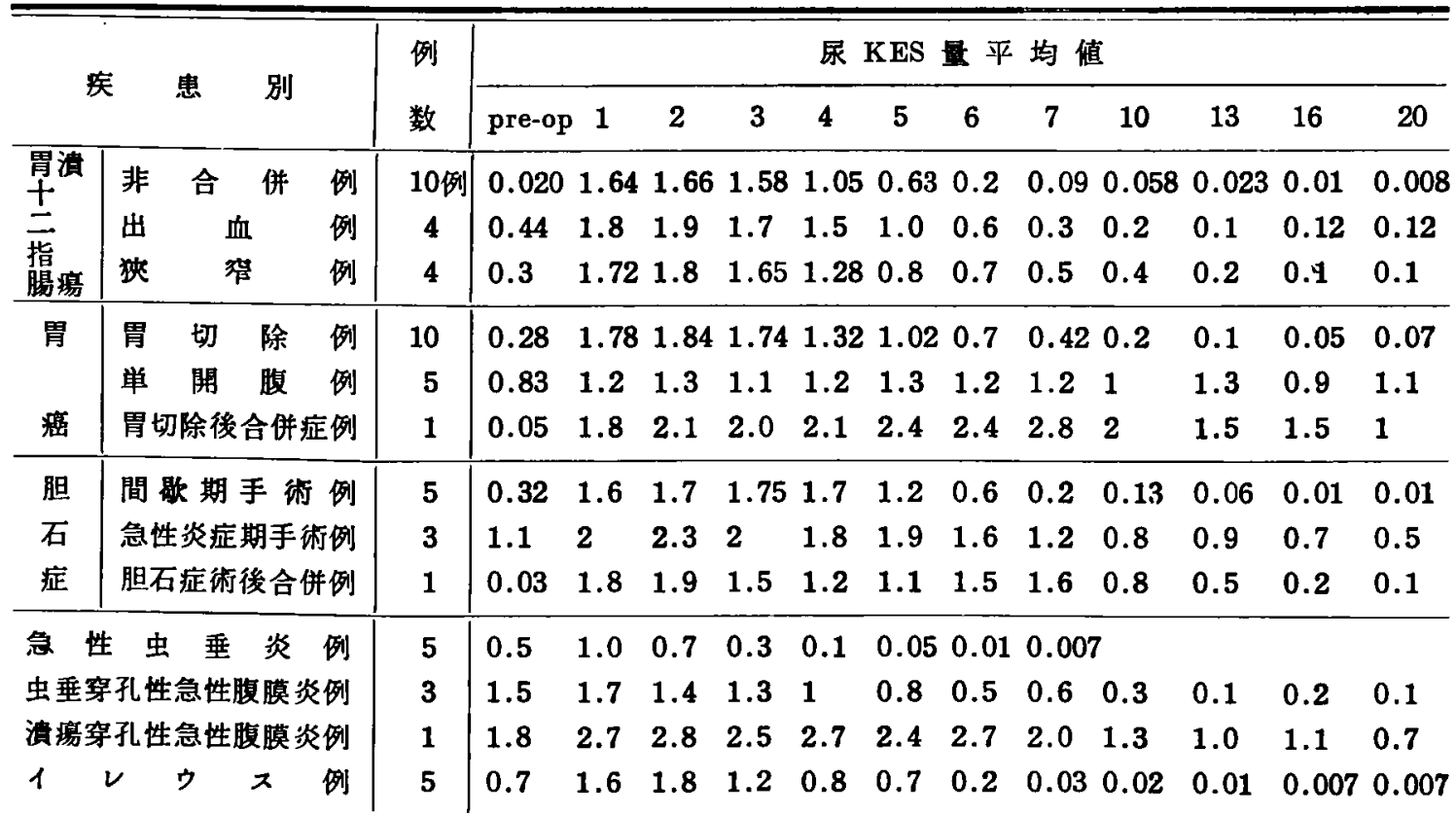

第 1 四 胃十二指腸溃湯非合併例（10例平均）

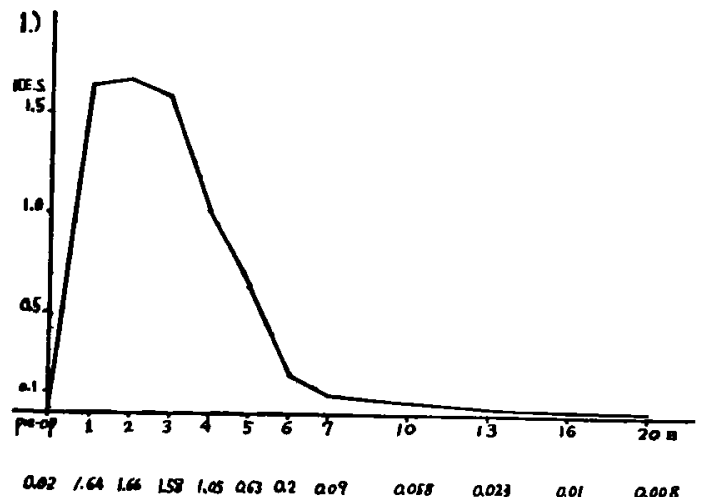

第 2 図 胃十二指腸㵝瘏出血例（4例平均）

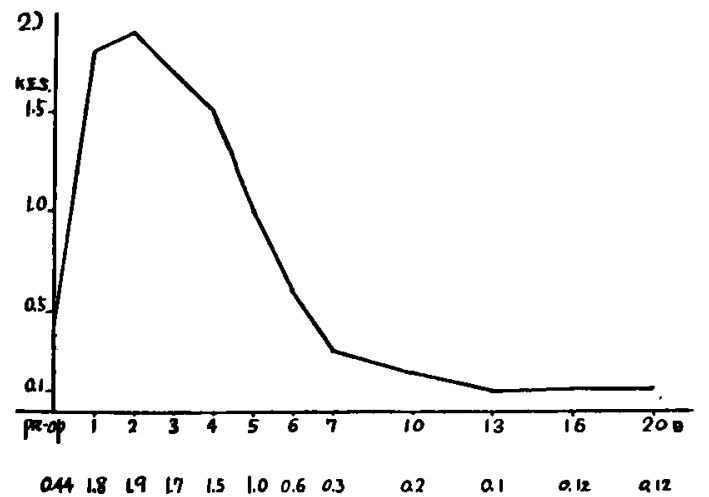

下となるか，第20日まで尚0.1以上の KES 量で正 常域に㸟らない.

八）狭窄例（第 3 図）

4 例，術前後にわたり $500 \mathrm{cc}$ 前後の新鮮血輸血

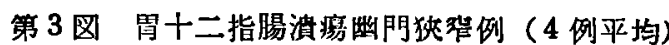

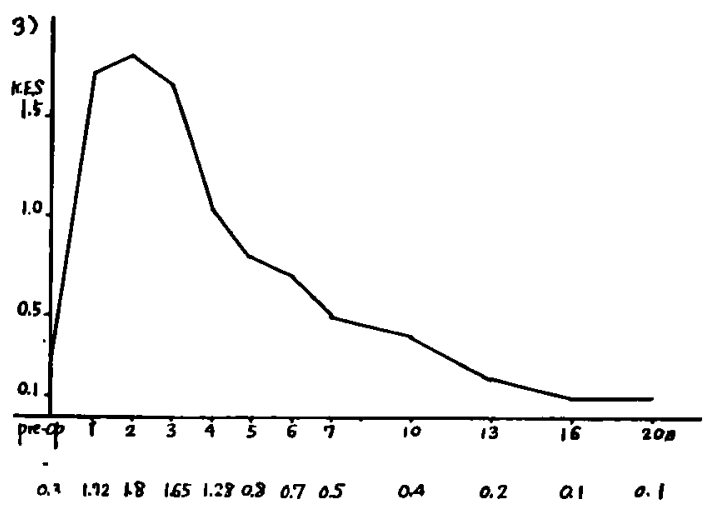

及び 5000〜 7000 cc の輸液を受けている. 術前平均 值0.3の高值, 術後第 2 日 1.8 で最高值, 第 7 日

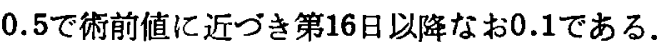

即ち非合併例，出血例，狭窄例共術後第 $1 \sim 3$ 日 著明に上开し以後下降して第 7 日には術前值に近づ きほぼ相似た経過を示すが，非合併例は第16日以降 正常域に入るに対し，出血例，狭窄例共術後第20日 に於てなお 0.1 程度で恢復がおくれている。

第 2 項 胃癌の場合

症例を 3 群にわけて述べる，イ）群は術前の通過 障碍も著明でなく術後合併症なく順調に経過した胃 切除例で，口）群は根治手術不能で単開腹に終つた 症例であり，八）例は１）群と同様に術前状態良 好であつたが術後第 6 日，十二指腸断端の䋖合不全 に対し再開復術，ト゚レナーヂを施行し治瘾し得た 1 
例である。

1）胃切除例（第 4 図）

10例，術前後を通して何れも $500 \mathrm{cc}$ 前後の新鮮 第 4 図胃癌胃切除例（10例平均）

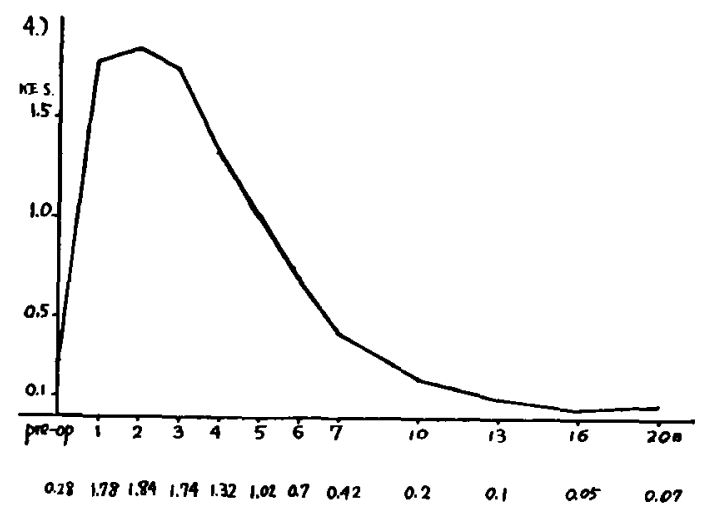

血輸血，約5000 cc の輸液を受けている，待前平均 值0.28，術後第 $1 ， 2 ， 3$ 日之著明に增量し第 2 日 1.84 で最高值，以後下降して第 5 日 1.02 ，第 7 日 0.42 となるが術前值よりなお高く第20日に及んです 0.07でなお正常域に至らない。

口) 単開腹例 (第 5 図)

5 例，術前 0.83 の高值を示し術後第 2 日1.37の最 第 5 目 胃癌単開腹例（5 例平均）

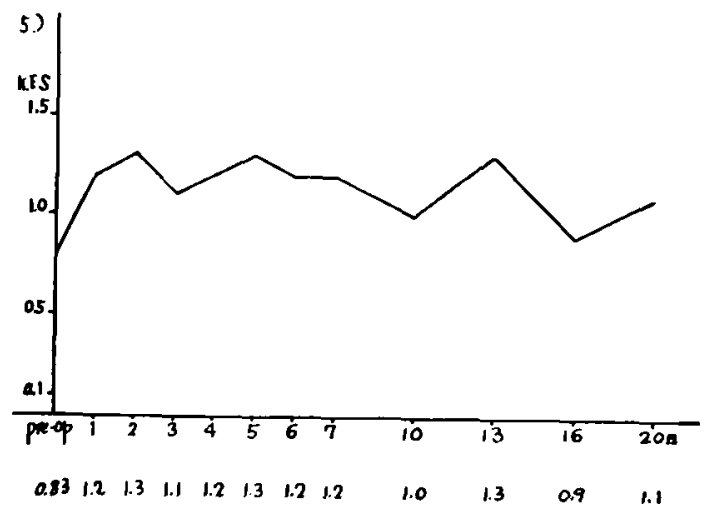

高値を示すが第 5 日，第 13 日むなお 1.3 前後の高值 を示し結局術前の高值が術後更に増加し以後第20日 に至るも1.1の著明の高値を示し術前よりも更に増 量のままである.

八) 術後合併症例（第 6 四）

1 例，十二指腸断端の綎合不全のため第 6 日再開 腹した症例では術前0.05より術後第 2 日2.1と增蒝 しその後第 4 日，5 日と更に增量し第 6 日に再閒腹 ドレナーヂ後第 7 日には2.8と著明に增虽したが以 後臨床症状の改善と共に下降し第20日には.1.0まで となつたがなお著明の高值を示している。

第 6 図 胃癌胃切除後十二指腸断端縒合不全例

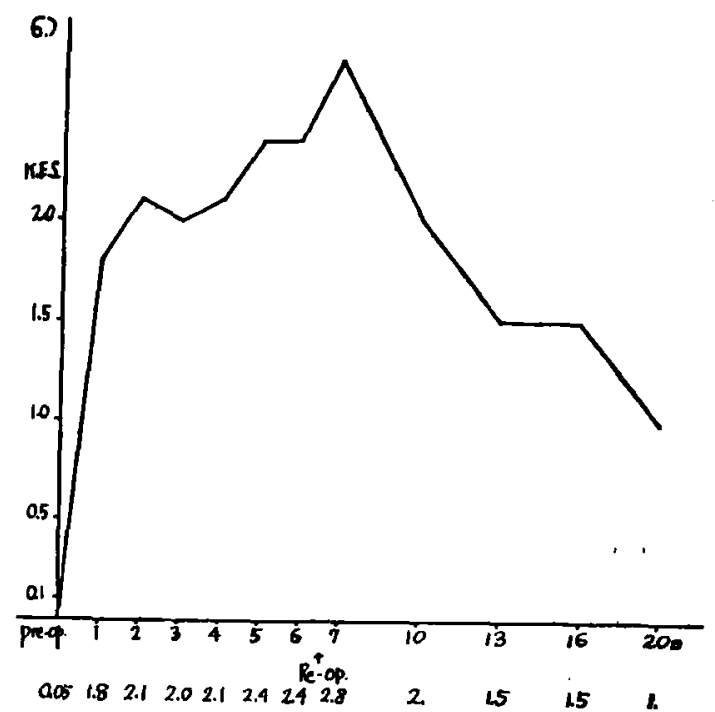

以上の如く胃癌では胃溃瘍，十二指晹清場に比べ て術前值は高く殊に単開腹の止むなきに至つた根治 手術不能例では殊に著明な高值を示した。胃切除例 では術後の経過は清瘍例とほぼ同様の曲線を描き術 後第 7 日には術前值に近つくくがなお潰痬に比較し高 值を示し 3 週後む此較的高值を示し清湟非合併例の 如くには正常域化帰らない，単開腹例術後では改善 を認め得ず又術後合併症では術後第 1 ～ 3 日の媔点 より下降を認めず, 再開腹後は殊に著しい高値を示 して後渐くKES 量の低下を来すが第1次手術後第20 日，第 2 次手術後第14日でなお1.0の高值を示した。

第 3 項 胆石症の場合

3 群に分けて述べ．1）群は間歇期手術例で最 近熱発，黄但等の急性炎症々状を認めず所謂間歇期 の胆毫剔出例である，口）群は急性胆軎炎の状態で 止むなく胆咅剔出術を施行した症例である。） 八)は 間歇期手術例で術後肺炎を合併した例である。手術

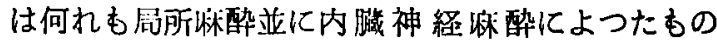
て，術前後を通じて輸血量は $500 \mathrm{cc}$ 程度で輸放は $5000 \mathrm{cc}$ 前後である.

1）胆石症間歇期胆婁剔出例（第 7 因）

5 症例の平均值に就て観るに，術前值では0.32で 潰瘍非合併例，胃癌罢切除例術前平均值上り高いか 術後の経過は第 $1 \sim 4$ 日，1.6 1.7で術直後の最高 值持続期間がやや長く，最高侹を示す日が溃瑒，胃 癌例加第 2 日に対し本症例では第 3 日で1.75であつ た。 以後念峻に下降して術後第 7 日0.2 と術前值以 下となる。第 2,3 週で更に減少し第16日以降は 溃晹非合併例之同様儿正常域任至る. 
第7図 胆石症間歇期手術例（5 例平均）

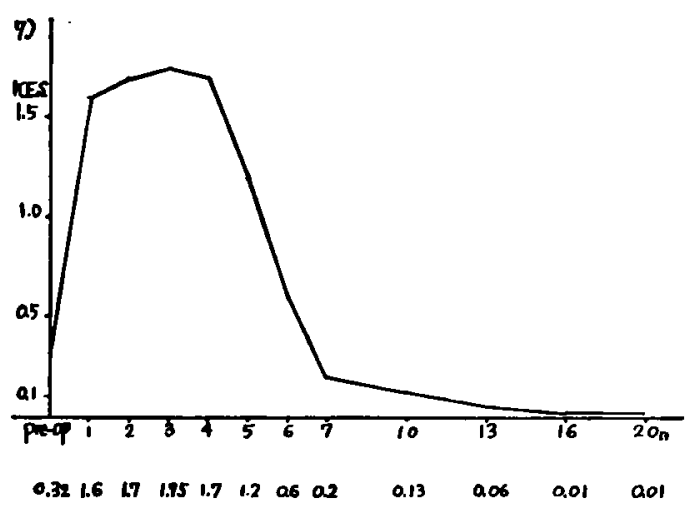

口）急性胆軎炎胆毫剔出例（第 8 四）

3 例の平均值に就てみるに術前 1.1 の著明な高値

第 8 园 急性胆のう炎（ 3 例平均）

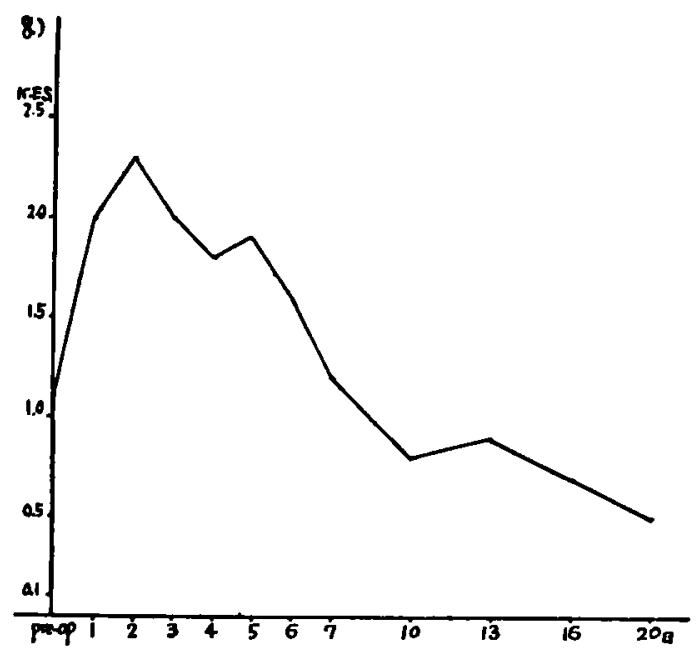

$\begin{array}{llllllllllllll}1.1 & 2 . & 2.3 & 2 . & 1.8 & 1.9 & 1.6 & 1.2 & 0.8 & 0.9 & 0.7 & 0.5\end{array}$

を示し術後第 2 日最高值 2.3 亿達し以後徐々に下降 するが第 7 日1.2でほぼ術前值に近づく，第20日に 於ても0.5の高值であつて，何れもドレナーヂ持続 例である.

八）術後肺炎合併例 (管 9 四)

間歇期手術例で術後第 7 日肺炎合併例では術前 0.03 の比较的低值であつたが術後第 2 日 1.9 に上昇 後下降し第 4 日 1.2 ，第 5 日 1.1 であつたが第 6 日 1.5 ，第 7 日 1.6 と上昇し第 7 日肺炎之診断治療处 り第10日0.8となり肺炎の治瘾と共に尿 KES は下 降したが第20日に於ても0.1で 1）群に比較して恢 復は遅延した。

即与間歇期手術例では清場非合併例に比べ術前後 共高值を示すが以後の板復は著明で第3週ではほほ 同程度となり正常域に入る. 急性炎症期手術では更
第 9 図 胆石症術後肺炎合併例

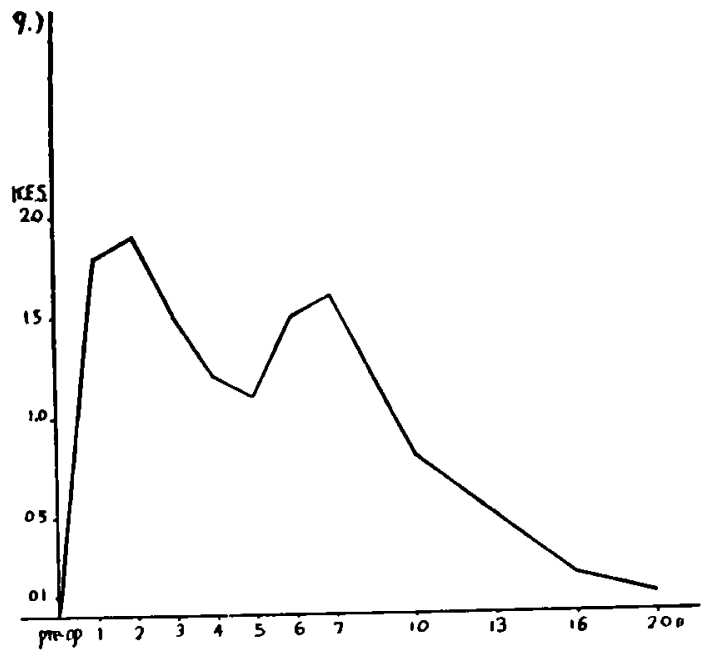

$\begin{array}{lllllllllllll}0.03 & 1.8 & 19 & 1.5 & 1.2 & 11 & 1.5 & 1.6 & 0.8 & 0.5 & 0.2 & 0.1\end{array}$

に著明の術前後の高値を示し術後第 3 週に於ても可 成り高度の疲労状態を示す. 又間歇期手術の 1 例で 術後肺炎合併例では発病と共に尿 KES は増量し以 後の㤆復は遅延した。

第4 項 急性虫垂炎の場合（第10図） 非穿孔性急性虫垂炎の 5 例では術前平均值0.5,

第10圀 急性虫烡炎例（5 例平均）

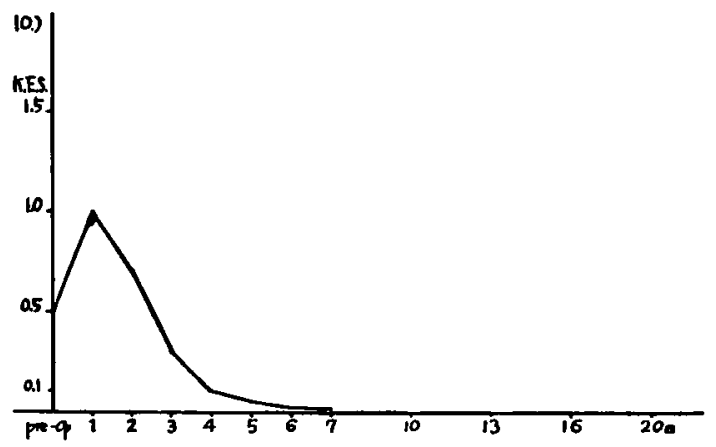

$05 \quad 10 \quad 0.7 \quad 0.3 \quad 0.1 \quad 0.500010009$

術後第 1 日 $1.0 て ゙$ 最高值，以後急峻に下降して第 4 日0.1, 第 6 日 0.01 之正常域汪入る.

即ち安原，小林，時岡とほぼ同様の成績であり術 前值は第 1 3 項の各疾患比比へ高いが術後の上昇 度は少く以後急速に恢復して第 6 日以後正常域に入 る.

第 5 項 急性腹膜炎の場合

2 群に分けて述へる， 1）群は虫垂穿孔性急性腹 膜炎 3 例で，口）群は溃瑒穿孔性急性腹膜炎の 2 例 である.

1）虫垂穿孔性急性腹膜炎症例（第11図）

3 例の平均值では術前値1.5の 著明な高値を示し 
第11図 虫垂穿孔性急性腹膜炎例（3 例平均）

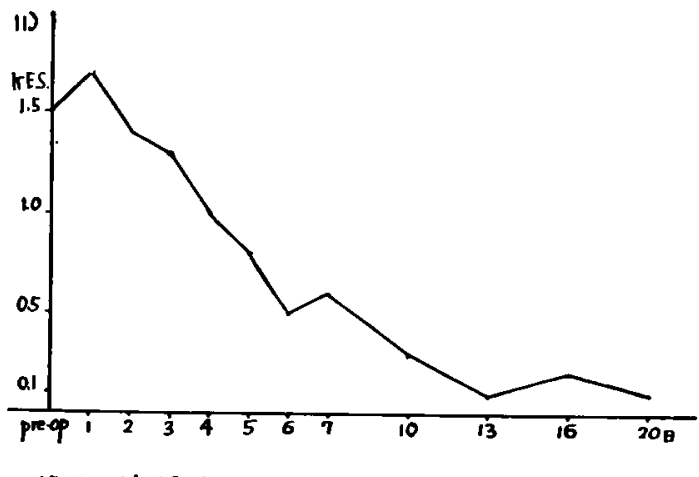

$\begin{array}{lllllllllllll}15 & 1.7 & 1.4 & 1.3 & 1 . & 0.8 & 0.5 & 0.6 & 0.3 & 0.1 & 0.2 & 0.1\end{array}$

溃癔非合併例の術後第 2 日の最高値 1.66 亿近く術後 第 1 日は 1.7 と夌駕するが，以後漸次減少して第 6 日0.5，第 7 日0.6，第 10 日0.3，第13日0.1，第16日 0.2 と動摇し第20日に於てもなお0.1を示す。

口）胃十二指腸溃瘍穿孔性急性腹膜炎（第12図） 1 例は胃潰瘍穿孔性急性汎発性腹膜炎で穿孔後約

第12因 溃瘍穿孔性急性腹膜炎

胃消瘏穿孔後32時間挠 OP. ……穿孔閉鎖ドレナー F, 死亡

十二指腸溃瑸穿孔後16時間後 OP. ......胃切除治痖

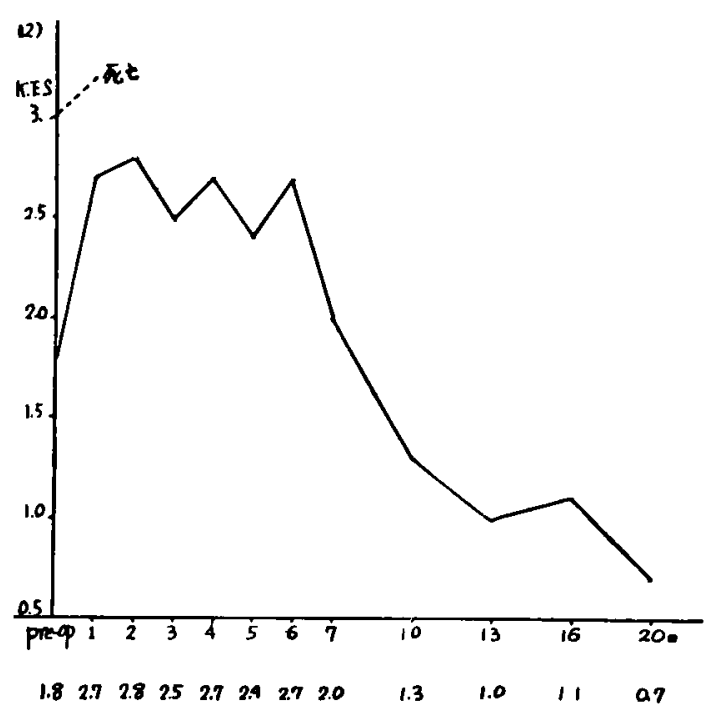

32時間で開腹，穿孔閉鎖ドレナーヂを施行したが術 後20時間で死亡せる例で術前 3.0, 術後10時間目の 尿で3.2と著明な」昇を示した。

他の 1 例は十二指腸溃瘍穿孔後16時間で開腹，幸 にも腹膜炎は右肝葉下より右側腹部右下腹部に主と し，胃切除可能で救命し得た例である，術前值は 1.8，術後第 6 日目まで2.8〜2.4の間を動摇したが 以後順調に絓過し第 7 日2.0，第10日 1.3 之減少し第
20日には 0.7 まで低下した，本例は術後30日で治虑 退院時には尿 KES は0.1まで減少していた。即ち 急性腹膜炎では尿 KES は腹部疾患中最も著明の増 量を示しその度合は前章に述べた如くほほ腹膜炎の 重篤度に一致するが術直後の増量度, 増量の期間む 同様に之に相応するようである.

第 6 項 イレウスの場合（第13罒）

主として瘺着性イレウスの 5 例に就きその平均值 第13図 イレウス例（5例平均）

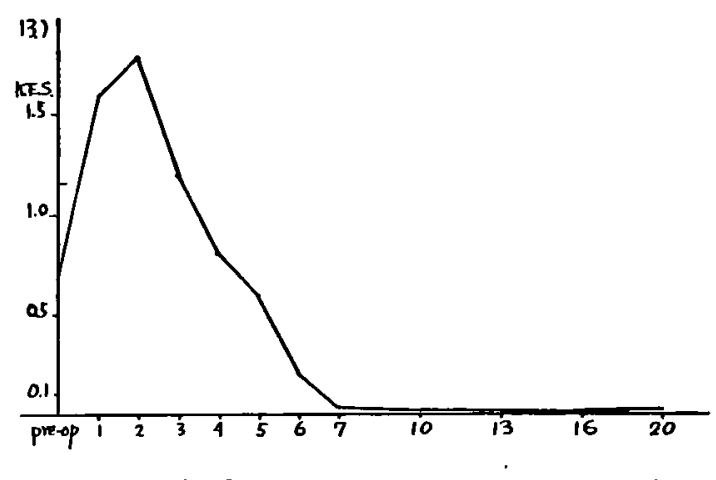

よりみれば術前値0.7で非穿孔性虫垂炎の平均值0.5 よりも高くイレウスの重篤な疾病なるととを反映す 万. 術後第 1 日 1.6 , 第 2 日 1.8 と上㫒するが以後は 急激に减少し第 5 日 0.6 ，第 7 日0.03 と低下し第 13 日以後は0.01以下の正常域に入る.

第4節 小 括

手術的侵㜔によつて術後 KES 排泄量の増加する ことは既に一般に認められている。然しながら腹部 外科的疾患の術前後に関する報告は少い．私は比较 的大きな開腹術前後の早朝尿KES量を測定して次の 結果を得た。

1）術後経過良好なる場合

1）非炎症性疾患では KES 量は術前值に比べ術 後第 $1 \sim 3$ 日著明に増量し以後速やかに下降して第 7 日頃には術前值に近つく. 更化街挠第 2,3 週と 下降し第 3 週の末には正常域に入る例が多い，但し 胃癌は潰瘍非合併症例に比較して術後の尿 KES の 减量はやや遅延し殊に根治手術不能例では術後20日 に於ても術前值に帰らない。

口）急性炎症性疾患では一般に 1)に比へて術 後の KES 量上异度は高く著明の増量期間は長く術 後 1 週であなお著明の高值を示し以後の KES 量減 少はイ）に比べ䌅慢である，その程度は術前の炎 症の重篤度にほぼ相応じ術後の KES 暴の変動曲線 は臨床経過とほぼ一致する．但し炎症所見の比較的 
軽度の非穿孔性急性虫垂炎では術後第 7 日までに正 常域に㷌る。

2）術前後の合併症ある場合

夫々 KES 量は增加し術後の KES 量の正常域得 帰は遅延する。

3）以上により開腹術症例の早朝尿 K ES量の消長 を追及することは術後の恢復の経過亚びに予後判定 に役立つものと考える.

\section{第4 章 総括並ひに結論}

私は腹部の外科的各種突患に於ける浜崎氏尿 KES 量を早朝尿又は術前尿につき测定し且つ術前 後の尿 KES の変動を術後 3 週まで測定して次の結 果を得た。

1）早朝尿又は術前尿の KES 量は各種疾患共に 一般に正常域より高いが特に急性炎症性疾患では最 あ高度に増量し，急性炎症の重篤度に相応じて炎症 広汎且つ重篤なものほど高值を示す．非炎症性疾患 では悪性腫劰たる胃癌の末期例に最も著明に増量し 次に胆石症，胃癌切除例，胃十二指腸潰瘍の順であ る，溃漡非合併例は最も低值を示すが術前出血，狭 窄等の合併例では増量している.

2）術後の尿 KES の消長では一般に術後 $1 \sim 3$ 日著明の上昇を示して以後下降し第 7 日にはほぼ術

文

1）捠崎：岡山医学会誌，49；442，昭12年.

2）浜崎，三船，小川：岡山医学会誌，52；1728, 昭15年.

3)渡辺 ·周山医学会誌，54；2037, 昭17年.

4) 山川：岡山医学会誌，53；1931, 昭16年.

5）山川阔山医学会誌，54；2132，昭17年.

6）浜崎：岡山医学会誌，56；378，昭19年.

7) 重盛：浻山医学会誌，50；763，昭13年.

8）甲斐，中岡·医療，5，571，昭26年.

9) 小川：岡山医学会誌，61；65, 昭24年.
前値と等しくなる，非炎症性疾腎は更に KES 量は 減少して第 3 週には正常域に帰る。但し胃癌例, 出 血又は狭窄合併の惯湯は第 3 週に於ても正常域に帰 らず，胃癌単開腹例では第 3 週に於ても術前值より 好枟しない。

急性炎症性疾患では炎症の重篤なほど術後の高值 の程度及び高值持秽期間が長く以後の KES の減量 も釋慢で第 3 週に於てあ正常域に帰らない。但し単 純なる急性虫垂炎では術後第 7 日までに正常域に帰 る.

3）術前後の合併症ては尿 KES 量は增加し術後 の尿 KESの減易は遅延する。

4）以上より術前後の早朝尿 KES 量测定により 術後の恢復の経過，予後判定に充分に役立つあの上 考えられる。

擱筆するにあたり御愁篤なる御指導，御校閲を賜 つた恩師津田誠次名誉教授並倸砂田輝武教授，御指 導を睗つた横田浩博士に深甚の謝意を表する。

(本論文の要旨は昭和26年 4 月第51回日本外科学 会総会並飞同年 6 月第26回中国四国外科学会飞於て 発表した)

\section{献}

10）浜崎：疲労判定法，44，創元社刊，昭22年.

11) 西井：岡山医学会誌，51；2721，昭14年.

12）安原, 小林: 日本外科学会誌, $43 ; 1448$, 昭 17 年.

13）時岡：岡山医学会誌，59；39，昭22年.

14）難波：日本臨床結核，13；703，昭29年.

15）浜崎：岡山医学会誌，52；1873，昭15年.

16）小川：岡山医学会誌，61；65，昭24年.

17）洔岡：岡山医学会誌，63；302，昭 26 年. 


\title{
Fluctuation of Fatigue Reaction Before and After Laparotomy, and Its Relation to Early Ambulation and Thermal-Bath
}

\section{Part I. Fluctuation of Hamasaki's Keto-Enol Substance (KES) in Urine Before and After a Few Operations}

\author{
By \\ Yasuhiro NAKAHARA \\ From the Surgical Division of Balneological Institute, Okayama \\ University Medical School
}

Keto-enol substance in urine, matutinal or preoperative, wa detormined and traced for three weeks after operation, on various surgical cases of the abdomen. Results obtained were as follows.

1) Levels of KES in matutinal or preoperative urine were generallv higher than normal, especially in case of acute inflammatory disease, and the rate of increase was proportionated to extent and severity of the inflammation. Upon non-inflammatory diseases, KES was noticeably increased in the late stage of stomach cancer, successively cholelithiasis, stomach cancer resected, gastroduodenal ulcer in order. In the cases with uncomplicating peptic ulcer the level was markedly low, but in the cases with complication of bleeding or stenosis slightly increased.

2) In the postoperative course, urinary KES was markedly increased within one to three days after oparatron and later decreased until normal on the seventh day. In the non-inflammatory cases, KES was further decreased and returned to normal after three weeks. In the cases of stomach cancer and peptic ulcer with complication of bleeding or stenosis, on the other hand, KES was not become normal even after three weeks of operation. In the cases of stomach cancer simply laparotomized, KES was not recovered to preoperative level even after three weeks of operation.

In the cases with acute inflammation the grade and duration of high leveled KES were marked with severity of inflammation, and later decrease in KES was also retarded, not becoming normal level even after three weeks of operation. In acuts simple appendicitis, though, the level became normal within seven days after operation.

3) In the cases with postoperative complications urinary KES was increased, and showed retarded decreasing rate.

4) From the results obtained above, it was concluded that determination of urinary KES before and after operation was valuable for judging the course of postoperative recovery and the prognosis. 